\title{
Facial Symmetry in Subjects with Full Dental Arches
}

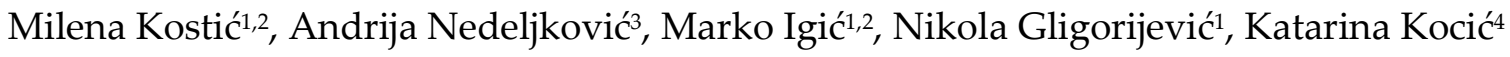 \\ ${ }^{1}$ University of Niš, Faculty of Medicine, Niš, Serbia \\ ${ }^{2}$ Clinic of Dental Medicine, Department of Prosthodontics, Niš, Serbia \\ ${ }^{3}$ University of Kragujevac, Faculty of Medical Sciences, Kragujevac, Serbia \\ ${ }^{4} \mathrm{PhD}$ Student, University of Niš, Faculty of Medicine, Niš, Serbia
}

\section{SUMMARY}

The universal notion of beauty does not exists, however, the facial symmetry contributes to a better aesthetic effect. This harmony is primarily determined by the relationship between parts of the face and dental parameters. Tooth loss leads to a decrease in the height of the bite and consecutive oncoming of the tip of the nose and chin and a violation of the vertical and horizontal relationship between the maxilla and mandible. dentition.

The aim of the study was to determine the interrelationship of facial parts in subjects with a full

The study included 60 dental students of both sexes in whom the presence of a complete dentition was determined by clinical examination. Facial parameters of the subjects' profiles were measured, as well as the ratio of bipupillary distance and intercommissural distance.

The obtained results partially confirmed the theory of matching the heights of the profile thirds and halves of the face. The values of the distance between the two pupils and the lip commissure did not differ statistically significantly. The obtained results could be used in the reconstruction of intermaxillary relationships after the loss of some or all teeth.

Key words: facial aesthetics, fascial parameters

Corresponding author:

Milena Kostić

e-mail: kosticmilena76@gmail.com 


\section{INTRODUCTION}

The face is the only part of the human body that is almost never covered, so it is constantly available to the aesthetic assessment of the environment, since it is in constant interaction with it. There is no universal notion of beauty and the saying "Beauty is in the eye of the beholder" is justified.

However, the harmony of individual facial structures significantly increases the possibility of liking someone. This harmony or "symmetry" refers, above all, to the ratio of parts of the face, ie. to its dominant thirds: - upper, - forehead or frontal, middle - nose or nasal and lower jaw, where they are expected to be of equal height $(1,2)$. Tooth loss leads to a decrease in the height of the bite and consecutive oncoming of the tip of the nose and chin, and a disturbance of the vertical and horizontal relationship between the maxilla and the mandible. Reducing the height of the lower third of the face violates its symmetry and thus its beauty, so the purpose of our dental profession can undoubtedly be sought in the aesthetic rehabilitation of our patients (3).

The beauty of the face is in its expression, and the face reveals the personality, emotions, especially its lower third (4). It can be said that the beauty of the face lies in a sincere and cordial smile. A beautiful smile means healthy and beautiful teeth. Changing the shape, size, color and composition of the teeth can disrupts the harmony of the dental arches, creates insecurity and deprives us of that smile. Reconstruction of structures should follow certain rules in order to return dental arches to the state before damage with a clearly determined ratio of the size of teeth, lips and other facial structures (5). The face is most often analyzed anthropometrically (directly on the subject's head), photometrically (photo analysis), cephalometrically radiological image (analysis) or by 3D computer analysis (6). The purpose of anthropometric measurements is to connect the points on the soft tissues of the face with horizontal and vertical lines, as well as to compare them with each other in order to obtain certain proportions (7). The face can be observed and analyzed from the front (en face) or from the profile, and depending on the observation method, horizontal and vertical aesthetic parameters of the face are distinguished (7). Vertical and horizontal facial parameters are var-iables and depend on gender, age, and racial population (1).
Considering these facts, a prospective clinical study was designed which examined the elements of facial symmetry by direct anthropometry in patients aged between 20 and 30 years, with a full dentition.

The aim of the study was to determine the interrelationship of facial parts in subjects with a full dentition.

\section{PARTICIPANTS AND METHODS}

The research was performed at the Clinic of Dentistry at the Faculty of Medicine in Niš, Department of Prosthodontics.

The subjects were dental students of both sexes in whom the presence of complete dentition was determined by clinical examination. The total number of respondents was 60 .

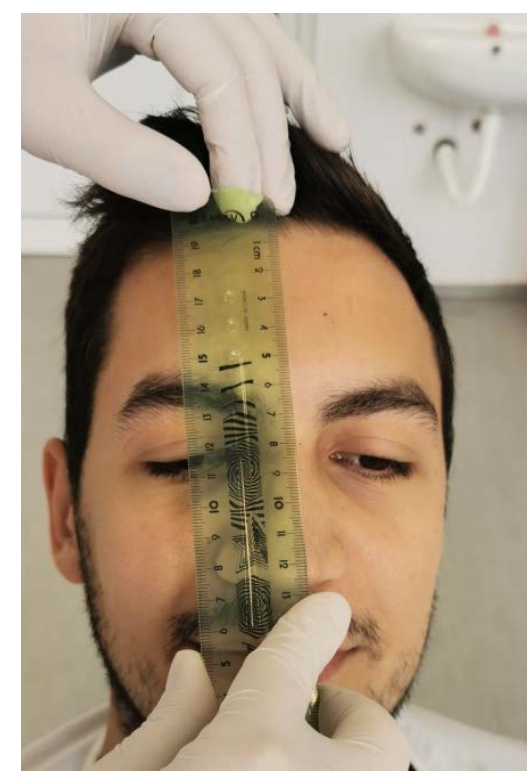

Figure 1. Measurement of the upper third of the face (from Trichion to Glabela)

The following measurements were performed by direct anthropometry:

- comparison of the height of the upper, middle and lower third of the face on the profile of the respondents: from Trichion to Glabela, from Glabela to Subnasale and from Subnasale to Gnathion (Figure 1).

- comparison of the distance from Trichion to Subnasale (upper half of the face) and the distance from the edge of the eye to Gnathion (lower half of the face) on the profile of the examinee (Figure 2).

- comparison of bipupillary distance and inter- 


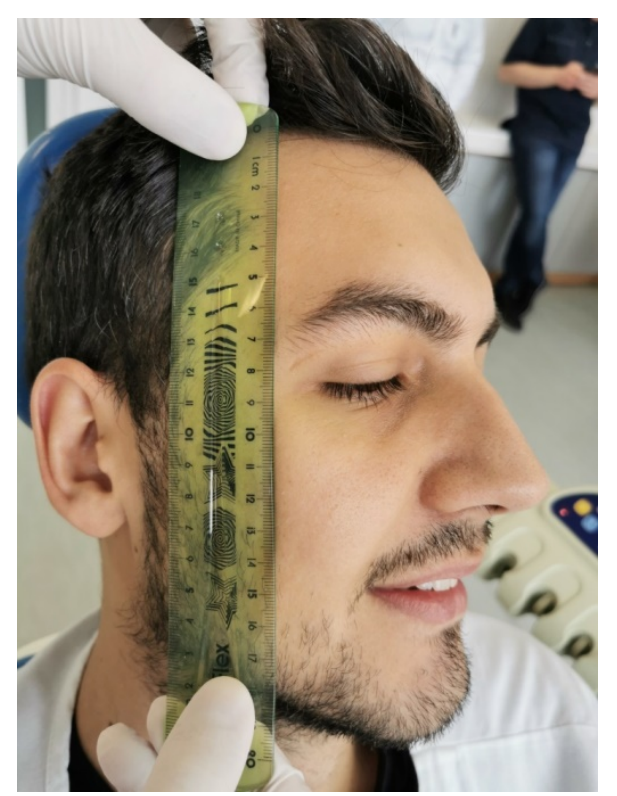

Figure 2. Comparison of the distance from Trichion to Subnasala (upper half of the face) and the distance from the edge of the eye to Gnathion (lower half of the face) on the profile of the respondents

commissural distance measured en face.

All measurements were performed in a dental chair with the help of a measuring instrument (flexible thirty-centimeter ruler). The measurements were in millimeters.

The measured values were entered in the table, and each of them corresponded to one of the columns.

Statistical measurements were performed in the Sigma Start program, using the Kruskal-Wallis One Way Analysis of Variance on Ranks. The level of statistical significance was $\mathrm{p}<0.05$.

\section{RESULTS}

Comparison of the measured thirds of the face (Kruskal-Wallis One Way Analysis of Variance on Ranks): (Table 1)

A difference in the mean values of the parameters of the height of all thirds of face can be observed,

Table 1. Comparison of heights of thirds of a person's face

\begin{tabular}{c|c|c|c}
\hline \hline Vertical face parameters & $\mathrm{N}$ & $\mathrm{X}(\mathrm{mm})$ & SD \\
\hline 1- upper third of the face & 60 & 62,000 & 6,705592573 \\
\hline 2- middle third of the face & 60 & 64,000 & 5,891677555 \\
\hline 3- lower third of the face & 60 & 68,000 & 6,346403403 \\
\hline \hline
\end{tabular}

and the statistical significance was determined by all pairwise multiple comparison procedures (Tukey Test) (Table 2).

Table 2. All pairwise multiple comparison procedures (Tukey Test) used to compare the heights of face thirds

\begin{tabular}{c|c|c|c}
\hline \hline Comparison & Differences in rows & $\mathrm{q}$ & $\mathrm{P}<0,05$ \\
\hline $\mathbf{3}$ vs $\mathbf{2}$ & 2659,000 & 6,588 & yes \\
\hline $\mathbf{3}$ vs $\mathbf{1}$ & 2309,000 & 5,721 & yes \\
\hline $\mathbf{1}$ vs $\mathbf{2}$ & 350,000 & 0,867 & no \\
\hline \hline
\end{tabular}

Based on the obtained values, it can be noticed that the height of the lower third of the person's face differs statistically in relation to the upper and middle third of the person's face.

The next groups compared were halves of face profiles. (Table 3.)

Table 3. Comparison of face halves

\begin{tabular}{l|l|l|c}
\hline \hline Vertical face parameters & $\mathrm{N}$ & $\mathrm{X}(\mathrm{mm})$ & SD \\
\hline 1- upper half of the face & 60 & 105,000 & 11,36080088 \\
\hline 2- middle half of the face & 60 & 100,000 & 17,54815811 \\
\hline \hline
\end{tabular}

Using the Kruskal-Wallis one-way analysis of variants by rank, we obtained larger differences in mean values between the halves of the faces than was expected (there is a statistically significant difference). We confirmed exactly these facts by a multiple row comparison procedure (Tukey test) (Table 4).

Table 4. Tukey test used to compare the dimensions of face halves

\begin{tabular}{c|c|c|c}
\hline \hline Comparison & $\begin{array}{c}\text { Differences in } \\
\text { rows }\end{array}$ & $\mathrm{q}$ & $\mathrm{P}<0,05$ \\
\hline $\mathbf{2}$ vs $\mathbf{1}$ & 1960,000 & 7,274 & Yes \\
\hline \hline
\end{tabular}

Finally, two horizontal dimensions of the face were analyzed: intercommissural distance and bipupillary distance (Table 5). The differences in the mean values between the groups are not large enough to exclude the possibility that the difference is due to the variability of random sampling (there is no statistically significant difference) $(P=0.502)$. 
Table 5. Comparison of intercommissural and bipupillary distance (Kruskal-Wallis one-way analysis-of-varianceby-ranks test)

\begin{tabular}{c|c|c|c}
\hline \hline $\begin{array}{c}\text { Horizontal face } \\
\text { parameters }\end{array}$ & N & $\begin{array}{c}\mathrm{X} \\
(\mathrm{mm})\end{array}$ & SD \\
\hline 1-intercommissural distance & 60 & 58,000 & 4,40326022 \\
\hline 2- bipupillary distance & 60 & 58,000 & 4,83758823 \\
\hline \hline
\end{tabular}

\section{DISCUSSION}

Aesthetics is based on the harmony and balance of the parts that make up a person's face, therefore the beautiful is often identified with the symmetrical (8). The discovery of the laws according to which the physical characteristics of the face (symmetry, shape, position and size of the parts of the face) affect the aesthetic assessment of the observer was the focus of this research (9). The aim of the study was to determine and prove the relationship of parts of the face, which was conducted by certain measurements on a group of respondents. The determination of the mentioned parameters had the task to confirm the relations of parts of the face and oral cavity, adopted in the literature, in the young population, with preserved dental health and intermaxillary relations.

The simplest analysis of the profile in the vertical is the one according to which the profile is divided into three floors: upper, middle and lower, which should be of the same height (2). Based on the obtained values in the examined group, it can be noticed that the height of the lower third of the face is statistically different in relation to the other two thirds of the face. These results are not in line with our expectations and can be explained by the fact that the lower third of the face is most susceptible to height variations due to the presence of different types of occlusion. There is no statistically significant difference between the height of the upper and middle third of the face.

By comparing the two profile halves of the faces, we obtained a statistically significant difference in their height. The obtained results can be explained by the fact that the mandible is differently developed in different people and by the fact that not everyone has the same bite. The values of persons with class II or III according to Angle differ significantly from persons with class I in the value of the height of the examined halves of the faces mea- sured on the profile. Although our subjects did not have pronounced skeletal orthodontic anomalies, changes in the position of the lateral teeth and minor dentoalveolar irregularities could affect the obtained results (10).

By comparing the total incisor width and intercanine distance, a statistically significant discrepancy was obtained. This proved that in the group of subjects there was no inclination and rotation of the frontal teeth, but their position was correct and pleasing to the eye. In this way, we, among other things, proved the correct choice of respondents in the study, which confirms the relevance of other obtained results. According to Lejoyeux, there is a certain ratio of the width of the central and lateral incisors, ie. the canine, so that its width corresponds to the sum of the lateral incisor and the canine (11).

It is interesting that the value of the distance between the two pupils and the two commissures of the lips coincided. Preserved bone alveolar support and the presence of all teeth result in competent lips with a pronounced and supported vermilion. The appearance of the lips is an important aesthetic determinant in today's world, especially for women. However, with the loss of teeth and changes in the ratio of the jaws, the lips lose their support, their vermilion decreases, and the corners (commissures) fall (10). By respecting the relationship between intercommissural and bipupillary distance, the lips can be reconstructed in the position and shape they had in youth, although optimal orthodontic positions do not guarantee the optimal position of soft facial structures $(11,12)$.

The obtained deviations did not make the examined group of dental students less beautiful. If the found deviations from the expected values of the measured parameters could be called "asymmetries", they are compensated by nature, so the general impression is that we worked with a group of attractive people. The determination of patterns and checking them on the population that has preserved teeth and occlusal relations is important in reconstructive dentistry, where prosthetic therapy should follow the guidelines for finding the optimal ratio of the lower third and half to the rest of the face. This explains people's desire for perfectionism and long-term attractiveness and their attempts to overcome personal aesthetic shortcomings and harmonize them with the traits that are considered "normal" (13). 


\section{CONCLUSION}

The obtained results partially confirmed the theory of matching the heights of the profile thirds and halves of the faces. Namely, there was a statistically significant difference in the height of the lower third in relation to the other two thirds of the face, as well as in the relation of the dimensions of the two profile halves of the participants' faces. The values of the distance between the two pupils and the lip commissure did not differ statistically significantly. The obtained results could be used in the reconstruction of intermaxillary relations after the loss of some or all teeth.

\section{References}

1. Galzignato P, Bertossi D, Albanese M, et al.. Variations of the profile of the nose of the upper lip. Minerva Stomatol. 2019;68(3):105-11. https://doi.org/10.23736/S0026-4970.17.04007-9

2. Perović T. Facijalni profil - harmonija i estetika. Glasnik Antropološkog društva Srbije 2018; 53: 107-17.

https://doi.org/10.5937/gads53-18516

3. Mack MR. Facially generated occlusal vertical dimension. Compend Contin Educ Dent. 1997;18(12):1183-6, 1188, 1190 passim; quiz 119. PMID: 9656843.

4. Zhao Q, Zhou R, Zhang X, et al. Morphological quantitative criteria and aesthetic evaluation of eight female Han face types. Aesthetic Plast Surg. 2013;37(2):445-53.

https://doi.org/10.1007/s00266-013-0081-9

5. Sarver D, Jacobson RS. The aesthetic dentofacial analysis. Clin Plast Surg. 2007;34(3):369-94. https://doi.org/10.1016/j.cps.2007.05.008

6. Harrar H, Myers S, Ghanem AM. Art or Science? An Evidence-Based Approach to Human Facial Beauty a Quantitative Analysis Towards an
Informed Clinical Aesthetic Practice. Aesthetic Plast Surg. 2018;42(1):137-46.

https://doi.org/10.1007/s00266-017-1032-7

7. Mentus T, Marković S. Effects of symmetry and familiarity on the attractiveness of human faces. Psihologija. 2016; 49(3):301-11. https://doi.org/10.2298/PSI1603301M

8. Vučinić N, Tubbs RS, Erić M, et al. What Do We Find Attractive about the Face?: Survey Study with Application to Aesthetic Surgery. Clin Anat. 2020;33(2):214-22. https://doi.org/10.1002/ca.23455

9. Fishman LS. Individualized evaluation of facial form. Am J Orthod Dentofacial Orthop. 1997;111(5):510-7.

https://doi.org/10.1016/S0889-5406(97)70288-9

10. Orenstein NP, Bidra AS, Agar JR, et al. Changes in Lower Facial Height and Facial Esthetics with Incremental Increases in Occlusal Vertical Dimension in Dentate Subjects. Int J Prosthodont. 2015;28(4):363-70. https://doi.org/10.11607/ijp.4288

11. Samizadeh S. The Ideals of Facial Beauty Among Chinese Aesthetic Practitioners: Results from a 
Large National Survey. Aesthetic Plast Surg. 2019;43(1):102-14. https://doi.org/10.1007/s00266-018-1241-8

12. Bergman RT. Cephalometric soft tissue facial analysis. Am J Orthod Dentofacial Orthop. 1999;116(4):373-89
https://doi.org/10.1016/S0889-5406(99)70222-2

13. Frith C. Role of facial expressions in social interactions. Philos Trans R Soc Lond B Biol Sci. 2009;12;364(1535):3453-8. https://doi.org/10.1098/rstb.2009.0142

\title{
Simetrija lica kod ispitanika sa punim zubnim nizom
}

\author{
Milena Kostić1,2, Andrija Nedeljković́ ${ }^{3}$, Marko Igić1,2, Nikola Gligorijević1 ${ }^{1}$ Katarina Kocić4 \\ ${ }^{1}$ Univerzitet u Nišu, Medicinski fakultet, Niš, Srbija \\ ${ }^{2}$ Klinika za dentalnu medicinu, Služba zastomatološku protetiku, Niš, Srbija \\ ${ }^{3}$ Univerzitet u Kragujevcu, Fakultet medicinskih nauka, Kragujevac, Srbija \\ ${ }^{4}$ Univerzitet u Nišu, Medicinski fakultet, student doktorskih studija, Niš, Srbija
}

\section{SAŽETAK}

Univerzalni pojam lepog ne postoji, ali simetričnost lica doprinosi boljem estetskom učinku. Ta skladnost se odnosi, pre svega, na odnos delova lica, i dentalnih parametara. Gubitak zuba dovodi do smanjenja visine zagrižaja $i$ konsekutivnog približavanja vrha nosa $i$ brade $i$ poremećaja vertikalnog $i$ horizontalnog odnosa maksile i mandibule.

Cilj istraživanja bilo je utvrđivanje odnosa delova lica, međusobnog odnosa dentalnih parametara i odnosa dentalnih parametara prema strukturama lica kod studenata sa punim zubnim nizom.

U istraživanje je bilo uključeno 60 studenata stomatologije oba pola, kod kojih je kliničkim pregledom utvrđeno prisustvo kompletnog zubnog niza. Mereni su facijalni parametri profila ispitanika, kao i odnos bipupilarnog rastojanja i interkomisuralnog rastojanja.

Dobijeni rezultati su delimično potvrdili teroriju o poklapanju visina profilnih trećina i polovina lica. Naime, postojala je statistički značajna razlika u visini donje u odnosu na druge dve trećine lica, kao i u odnosu dimenzija dve profilne polovine lica. Interkanino rastojanje bilo je statistički značajno veće $u$ odnosu na ukupnu širinu sekutića. Vrednosti rastojanja između dve pupile i komisure usana nisu se statistički značajno razlikovale. Dobijeni rezultati mogli bi se koristiti u rekonstrukciji međuviličnih odnosa nakon gubitka pojedinih ili svih zuba.

Ključne reči: estetika lica, facijalni parametri 